\title{
Effect of botanicals and insecticides seed treatment and containers on seed longevity of black gram under natural ageing conditions
}

\author{
N. Amruta*, G. Sarika, Umesha, J. B. Maruthi and G. V. Basavaraju \\ Department of Seed Science and Technology, University of Agricultural Sciences, GKVK, Bengaluru-560065 \\ (Karnataka), INDIA \\ *Corresponding author: amrutha.ngowda@gmail.com \\ Received: December 26, 2014; Revised received: March 19, 2015; Accepted: April 25, 2015
}

\begin{abstract}
Good storage is the basic requirement in seed production programme as maintenance of high seed viability and vigour from harvest to planting is of utmost importance in a seed production programme. Therefore, inexpensive, simple and practicable technology to prolong the shelf life of seeds under ambient condition is immensely needed. Hence, an experiment was carried out to study the effect of seed treatment with neem oil, nimbicidin, emamectin benzoate $5 \mathrm{SG}$, deltamethrin $2.8 \mathrm{EC}$, novuluron EC on black gram seed quality under ambient conditions. The seeds without any seed treatment were included as control. The treated and untreated seeds were stored in cloth bag and polylined cloth bag. The results revealed that, botanicals and emamectin benzoate seed treatments were significantly superior in controlling the storage insect and maintaining higher seed quality up to 10 months of storage when compared to control. Among the chemicals, the emamectin benzoate 5 SG @ $40 \mathrm{mg} \mathrm{kg}^{-1}$ of seed found better by recording significantly higher germination percentage (80.28), vigour index I (2124) and dry weight of seedlings $(43.14 \mathrm{mg})$ and lower electrical conductivity $(0.939 \mathrm{dSm}-1)$ and seed damage $(0.00 \%)$ compared to control $\left(78.78 \%, 2012,38.90 \mathrm{mg}, 0.942 \mathrm{dSm}-1\right.$, respectively) at the end of $10^{\text {th }}$ month of storage. The emamectin benzoate $5 \mathrm{SG}$ and nimbicidintreated seeds stored in polylined cloth bags were considered as effective seed storage management approach in blackgram.
\end{abstract}

Keywords: Blackgram, Botanical products, Emamectin benzoate, Insecticides

\section{INTRODUCTION}

Blackgram (Vignamungo (L.) Hepper), occupies a unique place among pulses for its use as seed and vegetable and it is grown both as pure and mixed crop. It is native to India, belong to the family Leguminaceae.It also suppliments the income of many small scale farmers and contributes to the maintance of soil fertility by fixing nitrogen in the soil. Black gramis rich protein food, contains about $26 \%$ protein, $1.2 \%$ fat and $56.6 \%$ carbohydrates on dry weight basis and it is rich source of calcium and iron.

The quality of seeds in storage is influenced by several factors like variety of seed, initial seed quality, storage condition, moisture content, insect pest, bacteria and fungi. The poor storage of black gram seeds is problem because of Callasobruchus chenensis (L.) and C. maculates (F.) belonging to the family of Bruchidae, which causes qualitative and quantitave losses. Therefore, maintenance of seed viability and vigour during storage is a matter of prime concern. The seed potentiation is mainly achieved by treating the seeds with various chemicals and botanicals can reduce the infestation and maintain the quality of the seed interm of vaibilty and vigour for longer period in storage (Duruigbo, 2010; Basavegowda and Arunkumar, 2013;. Maintenance of seed quality during storage period is important not only for successful crop production but also for maintaining the quality and integrity of the seed that are inconstant threat of genetic erosion (Barua et al.,2009). To maintain the quality of seeds during storage the standardization of suitable seed treatments and packaging material is most important because seed treatment is the basic measure to assure adequently healthy crops at emergence and during further growth of plants (Wani et al., 2014). Therefore, the purpose of this study was to determine the influence of botanicals, insecticides seed treatment and containers on seed longevity of black gram under natural ageing conditions.

\section{MATERIALS AND METHODS}

The experiment was carried under ambient conditions $\left(20.3 \pm 2.3^{\circ} \mathrm{C}\right.$ temperature and $50.5 \pm 6.3 \%$ relative humidity) at Department of Seed Science and Technology, University of Agricultural Sciences, Bengaluru during 2012-13. The experiment was laid out in completely randomized block design in 2 by 6 factorial with three replications. The black gram seeds (variety LBG 625 Rashmi) were put in two different packaging material (cloth bag and polylined cloth bag) in combination with different seed treatments like botanicals (neem oil (a) $5 \mathrm{ml} \mathrm{kg}^{-1}$, Nimbicidin 10,000 ppm i. e., @ $5 \mathrm{ml} \mathrm{kg}^{-1}$ 
and NovuluronEC $0.05 \mathrm{ml} \mathrm{kg}{ }^{-1}$ ) and insecticides (Emamectin benzoate 5 SG @ $40 \mathrm{mg} \mathrm{kg}^{-1}$ seeds, Deltamethrin 2.8 EC @ $0.04 \mathrm{ml} \mathrm{kg}^{-1}$ ) along with no treatment (control).

Data was collected on seed samples drawn from each treatment on the following parameters for bi monthly intervals upto ten months: seed moisture content (\%), seed germination (\%), mean seedling length $(\mathrm{cm})$, seedling vigour index-I, seed damage (\%), electrical conductivity $\left(\mathrm{dSm}^{-1}\right)$, total dehydrogenase activity and field emergence (\%). The germination test was conducted as per International Seed Testing Association (ISTA, 2007), the seedling vigour index- II was calculated by multiplying germination (\%) with mean seedling length $(\mathrm{cm})$ as suggested by Abdul-Baki and Anderson (1972). Seed damage in each treatment were determined by dividing the number of seeds from 100 randomly selected seeds with holes/ perforations by beetles by the total randomly collected seeds and expressed as a percentage. The seeds from each treatment were soaked in $25 \mathrm{ml}$ of distilled water for $24 \mathrm{~h}$ at $25 \pm 10^{\circ} \mathrm{C}$. The steeped water from soaked seeds was collected and the electrical conductivity (EC) of seed leachate was measured in digital conductivity meter (Model: Systronic conductivity meter 306)and was expressed as $\mathrm{dSm}^{-1}$. The total dehydrogenase activity was determined by method described by Perl et al. (1978) with slight modifications.

\section{RESULTS AND DISCUSSION}

The moisture content $(\%)$ of the seeds increased from fresh seeds to $10^{\text {th }}$ month of storage in cloth bag (8.00 to 9.93 ) compared to polylined cloth bag (8.00 to 8.38) irrespective of the chemicals used (Table 1). Cloth bag being a pervious container, moisture exchange took place frequently until it reaches the equilibrium status with environment where as polylined cloth bag is impervious nature and caused less fluctuation in seed moisture content and it eliminates dampness, deterioration, and micro-organisms and enhance the seed longevity. These results are also incongruence with Jaya et al. (2014), whorevealed that cloth bags recorded maximum moisture content at the end of 6-month storage period. Emamectinbenzoate treated seed maintained the highest germination percentage $(80.28 \%)$, mean seedling length $(26.73 \mathrm{~cm})$ and seedling vigour index I (2243) during storage period and seeds stored in 400 guagepolylined cloth bag recorded significantly highest germination per cent $(80.00 \%)$ (Table 1$)$ mean seedling length $(27.26 \mathrm{~cm})$ and seedling vigour index I (2152) (Table 2). It is due to emamectinbenzoate found effective in protecting black gram seeds from insect damage without any adverse effect on seed physical characters. The results are in agreement with Ghelani et al. (2009) in pearl millet where emamectin benzoate and deltamethrin also provided better over botanicals.

The electrical conductivity $\left(0.939 \mathrm{dSm}^{-1}\right)$ was lowest in Emamectin benzoate treated seeds and was low $\left(0.939 \mathrm{dSm}^{-1}\right)$ in 400 guagepolylined cloth bag container at the end of 10 months of storage (Table 3 ). The total dehydrogenase activity was highest in emamectin benzoate (0.730).The seeds stored in 400 guagepolylined cloth bag recorded significantly highest dehydrogenase activity (0.731) (Table.3).The marked decrease in the seed quality parameters under advancing storage period may be attributed to seed coat characters (Deloucheet al., 1973), age induced physicochemical seed deterioration, lipid peroxidation leading to production of toxic metabolites that act upon cell and cell organelles denaturation of proteins and enzymes (Roberts, 1972). Similar decline in seed quality parameters with advancing storage period was also reported by Pramila (2003) in black gram.

Seed damagewas nil in all the seed treatments and 400 guagepolylined cloth bag container at the end of 10 months of storage compared to control (Table.4) The treatment with insecticides significantly reduced the larval and adult population of bruchid beetles due to their ovicidal and inhibitory repellent properties. The similar results were reported by Ghelaniet al. (2009) in pearl millet. The field emergence percentage was highest in emamectin benzoate $(73.67 \%)$ and seeds stored in 400 guagepolylined cloth bag (73.11\%) (Table.4)may be attributed to the impervious nature to moisture vapours and thus it has caused less fluctuation in seed moisture content and seed infestation and thus indicating polylined cloth bag as a better storage container.

\section{Conclusion}

It is evident from present study that the seed stored in cloth bag showed poor quality parameter i.e. decreased germination, vigour and higher $\mathrm{EC}$ value due to increase seed quantitative losses and it might be ascribed to the increased activities of pulse bruchids due to greater fluctuations in moisture content in view permeable nature of cloth bag to moisture vapours. Hence these results indicated cloth bag as a poor container for storage of black gram seeds under ambient conditions, while the emamectin benzoate $5 \mathrm{SG}$ and nimbicidin treated seeds stored in polylined cloth bag were considered as effective seed storage management approach in blackgram.

\section{REFERENCES}

Abdul-Baki, A.A. and Anderson, J.D. (1972). Physiological and biochemical deterioration of seeds of soybean In: Seed BiologyII. Kozlowski (ed.). Academic Press, New York, London.

Barua, H., Rahman, M.M., Masud, M.M. (2009). Effect of storage container's environment at different storage period on the quality of chilli seeds. Int. J. Sustain. Crop Prod. 4(4):28-32.

Basavegowda, G.S. and Arun kumar, H. (2013). Effect of commercial cold storage conditions and packaging materials on seed quality of chickpea (Cicer arietinum.L). Glob. J. Sci. Front. Res. Agric. Vet. Sci. 13:2.

Duruigbo, C.I. (2010). Assessing the viability of maize and 


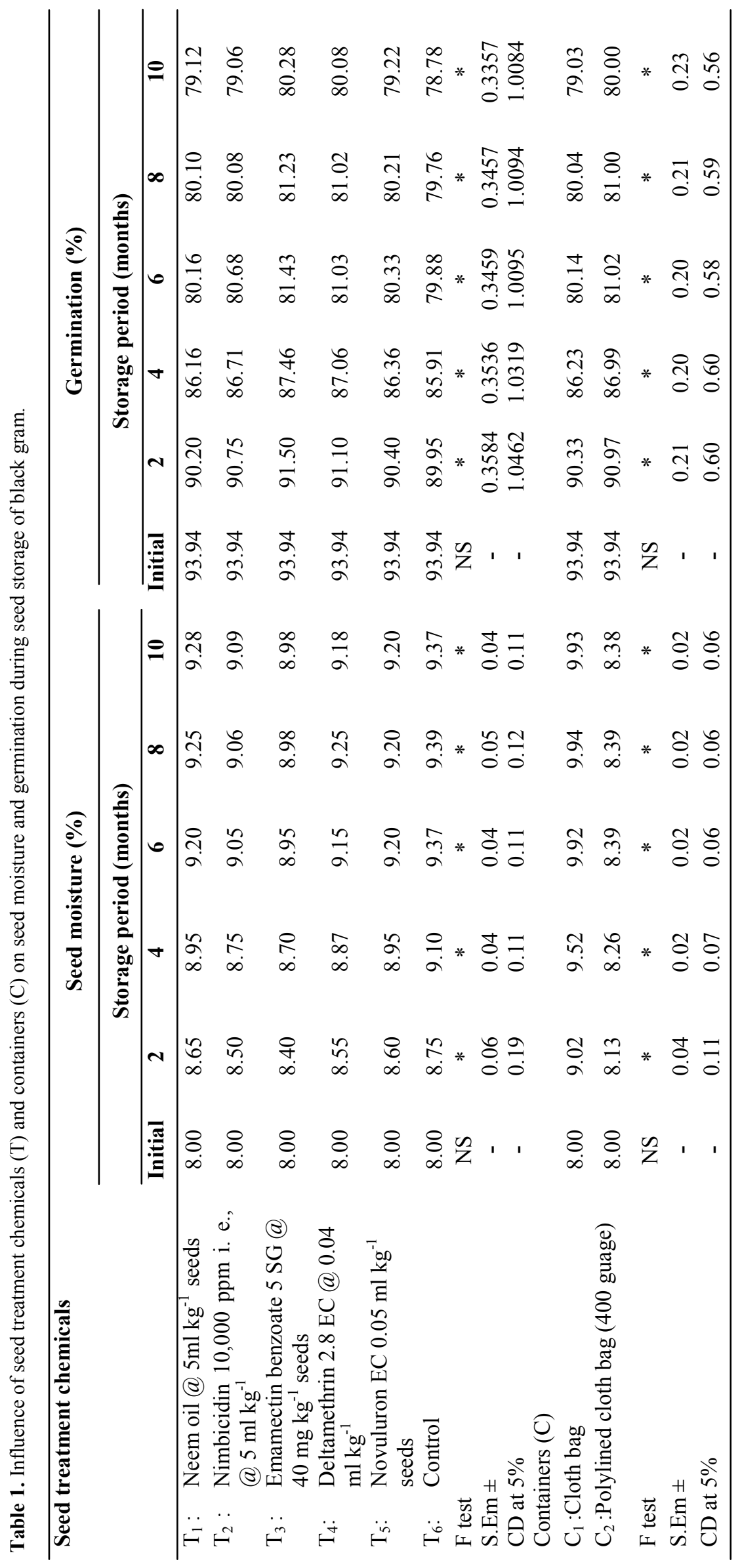


N. Amruta et al. / J. Appl. \& Nat. Sci. 7 (1) : 328 - 334 (2015)

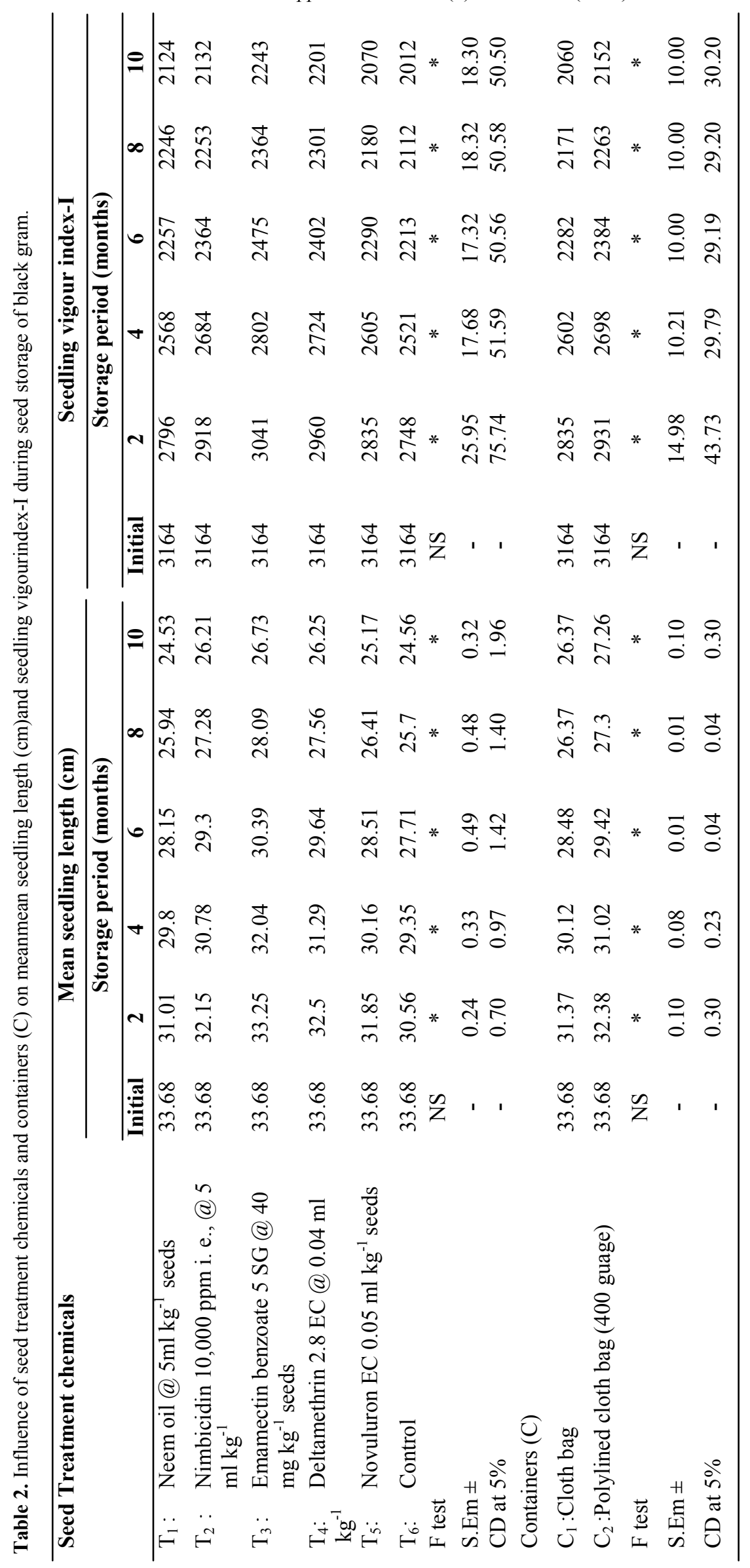


N. Amruta et al. / J. Appl. \& Nat. Sci. 7 (1) : 328 - 334 (2015)

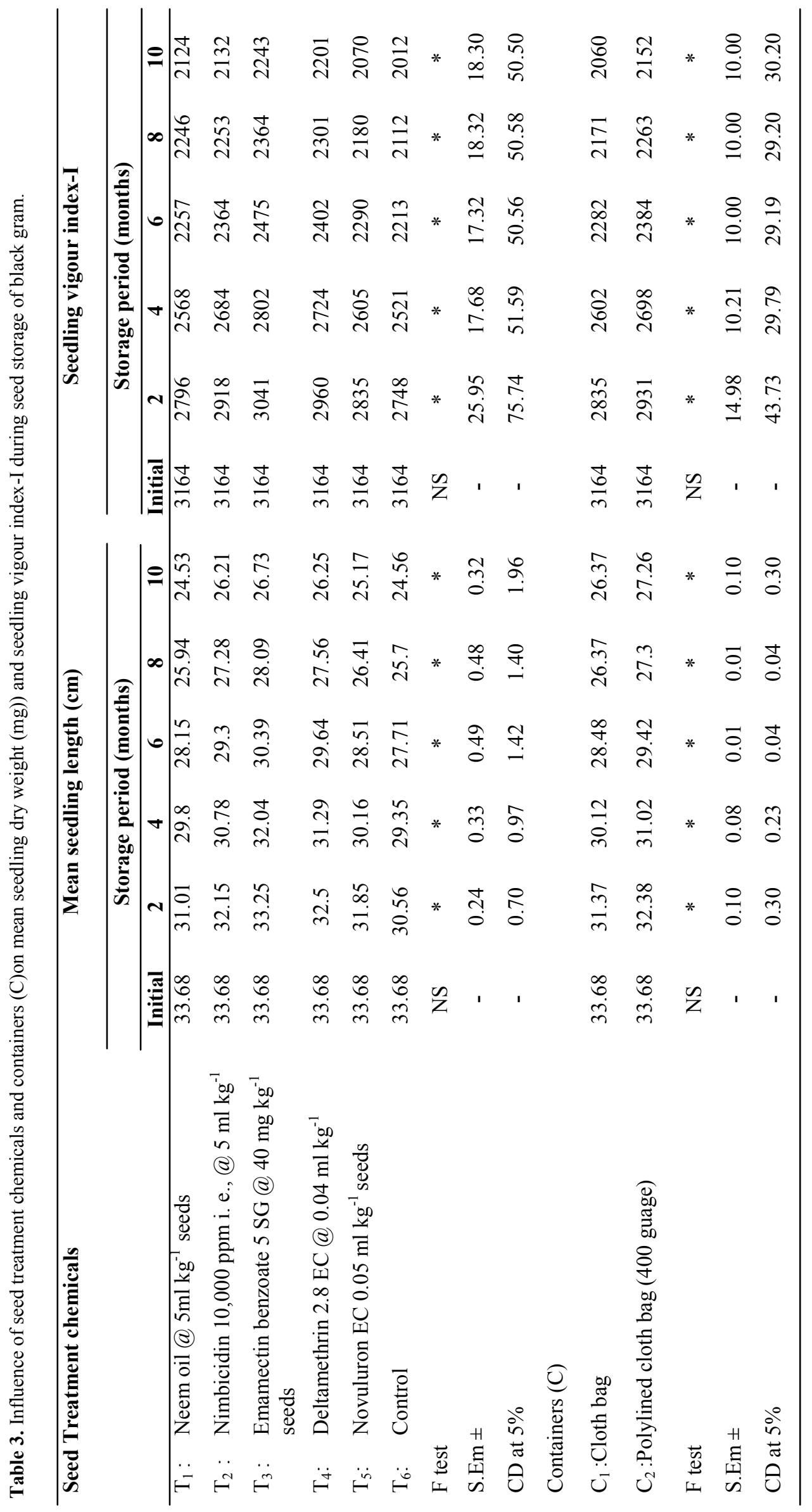


cowpea seeds stored using local plant biocides. New York Sci. J. 3:1-5.

Delouche, J.C., Matter R.K., Dougherty, G.M. and Boyde, A. H. (1973). Storage of seeds in tropical regions. Seed Sci. Technol., 1: 671-700

Ghelani, Y.H., Dhedhi, K.K., Joshi, H.J., Raghvani, K.L. and Dangaria, C.J. (2009). Effect of insecticidal seed treatment on viability of pearl millet seed during storage. Karnataka J. Agric. Sci., 22(3): 633-634.

ISTA, (2007). International Seed Testing Association. Seed Sci. and Technol, Vol. 27, pp.25-30.

Jaya, J, Wani A.A, Titov A, Tomar D.S. (2014). Seed Quality Parameters of Soybean (Glycine Max. L.) As Influenced by Seed Treating Fungicides and Botanicals and Packing Materials. India J. Appl. Res. 3(4):219-222.
Pramila R Gangal (2003). Influence of pre harvest insecticidal spray on seed yield and quality and post harvest seed treatment on storability of black gram (Vignamungo). M.Sc. (Agri.) Thesis, Univ. Agric. Sci., Dharwad, Karnataka (India).

Perl, M., Luria, I., and Gelmond, H., 1978. Biochemical changes in sorghum seeds affected by accelerated ageing. J. Expt. Bot., 29: 497-501.

Roberts, E.H. (1972). Storage environment and control of viability. In: variability of seeds. Eds. E.H. Roberts, Chapman and Hall Limited, London, pp. 14-18.

Wani A.A, Joshi J., Titov A, Tomar D.S. (2014). Effect of seed treatments and packing materials on seed quality parameters of maize (Zea mays L.) during Storage. India J. Appl. Res. 4(4):102-108. 